\title{
Biological Removal of the Mixed Pharmaceuticals: Diclofenac, Ibuprofen, and Sulfamethoxazole Using a Bacterial Consortium
}

\author{
Salima Aissaoui ${ }^{1}$, Houria Ouled-Haddar ${ }^{1,2}$, Mohamed Sifour ${ }^{* 1,2}$, Chérifa Beggah ${ }^{2}$, Farida Benhamada ${ }^{2}$ \\ ${ }^{1}$ Laboratory of Molecular Toxicology, Faculty of Nature and life Sciences, University of Mohammed Seddik Benyahia - Jijel, 98 Ouled \\ Aissa-Jijel 1800-Algeria, Algeria \\ ${ }^{2}$ Department of Applied Microbiology and Food Sciences, Faculty of Nature and Life Sciences, University of Mohammed Seddik Benyahia- \\ Jijel, 98 Ouled Aissa-Jijel 1800-Algeria, Algeria
}

"Corresponding author: Mohamed Sifour, Laboratory of Molecular Toxicology, Faculty of Nature and life Sciences, University of Mohammed Seddik Benyahia - Jijel, Algeria, E-mail: sifourm@yahoo.fr, Tel/ Fax: +213 34502687

Background: The presence of pharmaceuticals at low concentrations (ng to $\mu \mathrm{g}$ ) in the environment has become a hot spot for researchers in the past decades due to the unknown environmental impact and the possible damages they might have to the plantae and fauna present in the aquatic systems, as well as to the other living organisms.

Objectives: The aim of the present investigation was to develop a bacterial consortium isolated from different origins to evaluate the ability of such a consortium to remove a mixture of pharmaceuticals in the batch system at lab scale, as well as assessment of its resistance to the other micropollutants present in the environment.

Material and Methods: Using a closed bottle test, biodegradation of the mixed pharmaceuticals including Diclofenac (DCF), Ibuprofen (IBU), and Sulfamethoxazole (SMX) (at a concentration of $3 \mathrm{mg} . \mathrm{L}^{-1}$ of each drug) by the bacterial consortium was investigated. The test was carried out under metabolic (pharmaceutical was used as the sole source of carbon) and co-metabolic condition (in the presence of glucose). Finally, the ability of the bacterial consortium to resist other micropollutants like antibiotics and heavy metals was investigated.

Results: Under the metabolic condition, the mixed bacteria (i.e., consortium) were able to metabolize $23.08 \%$ and $9.12 \%$ of IBU, and DCF at a concentration of $3 \mathrm{mg} . \mathrm{L}^{-1}$ of each drug, respectively. Whereas, in co-metabolic conditions, IBU was eliminated totally, in addition, $56 \%$ of the total concentration of DCF was removed, as well. In both metabolic and cometabolic conditions, removal of SMX was not observed. The selected bacteria were able to resist to most of the applied antibiotics and the used heavy metals, except mercury, where only one strain (S4) was resistant to the later heavy metal. Conclusion: Results suggest that the developed consortium might be an excellent candidate for the application in the bioremediation process for treating ecosystems contaminated with the pharmaceutical.

Keywords: Bacterial consortium, Biodegradation, Co-metabolism, Mixed pharmaceutical.

\section{Background}

In the last decade, environmental pollution caused by pharmaceutical compounds has increasingly attracted researcher's interest due to their global distribution on one hand, and because they are designed to stimulate specific biological responses at very low concentrations, on the other hand (1). Pharmaceutical compounds are continuously released into sewage systems, most of which pass through wastewater treatment plants (WWTPs) and reach the surface, ground, and even drinking water as unchanged compounds, or, as their transformation products (2-3). More than 3500 pharmaceutical compounds excluding metabolites and transformation products have been detected in the different environmental compartments; they have been detected in aquatic environments, mainly in surface water and wastewater effluents. The non-steroidal antiinflammatory drugs (NSAID) represent the major class of detected pharmaceuticals (4-5).

Scientific attention is now focusing on the use of biological methods as an eco-friendly alternative for the removal of emerging pollutants (6). Biodegradation; a 
process of reactions that is catalyzed by the microbial community (bacteria, fungi, etc.), leading to the transformation (i.e., modification of certain functional groups) of the organic micro-pollutants or in most cases to the mineralization (7-8). Biodegradation of pharmaceuticals involves the conversion of the parent compound to metabolites by the action of microorganisms in WWTP or in the environment both in aerobic or anaerobic conditions (9). In aerobic conditions, microorganisms transform the molecules through successive oxidation reactions to give rise to more simple organic intermediates or mineral products $\left(\mathrm{CO}_{2}\right.$ and $\left.\mathrm{H}_{2} \mathrm{O}\right)$ (7). In anoxic conditions, drugs are converted partially, completely, or are partially mineralized with the production of methane and $\mathrm{CO}_{2}$ (10). The above reactions are catalyzed by several enzymes, for example diclofenac is converted to (4'-hydroxydiclofenac, 5-hydroxydiclofenac, and 4', 5-dihydroxydiclofenac) in Phanerochaete sordida through oxidation reactions by cytochrome P450, manganese peroxidase, and laccase which are the source of $90 \%$ removal of diclofenac after 6 days of incubation (11).

The genera Pseudomonas, Arthrobacter, and Enterobacter can use a wide and diverse range of organic substances such as pharmaceuticals as carbon and energy source. Enterobacter hormaechei and Enterobacter coloacea show an interesting degrading capacity of the pharmaceutical effluent (12). Similarly, several studies have reported the ability of the genus Pseudomonas and Arthrobacter for degrading the polluting compounds like sulfamethoxazole, chlorophenoxy acids, and pentachloronitrobenzene (13-15).

So far were, most of the reported studies have used single compounds (drugs) or single microbial strains; however these cases do not reflect exactly the real situation in WWTP and environment where pharmaceutical compounds are present in complex mixtures (6). In addition, the ecotoxicity of a pharmaceutical mixture is typically higher than the effects of a single component, even if all individual pharmaceuticals are present at low concentrations that do not provoke significant toxic effects if acting individually on the exposed organism (16).

Therefore, and in order to develop a biological system capable of removing such mixtures, diverse types of microbial strains needed to be used simultaneously as consortia (6). Most of the reports stated that microbial consortia exhibited higher biodegradation yields compared to the single strains (17-18). This study aims to develop a bacterial consortium, formed of four bacterial strains belonging to the genera known to be good biodegraders. The strains were previously isolated from different origins (i.e., activated sludge and household compost). Evaluation of its ability to aerobically remove a mixture of pharmaceutical compounds (SMX, IBU, and DCF) in a batch system at laboratory scale was studied. The drugs were used both as the sole source of carbon and in co-metabolic conditions in the presence of glucose. Our objective was extended to evaluate the ability of this consortium to resist other pollutants commonly present in the environment, namely heavy metals and antibiotics. The developed consortium may be employed for bioaugmentation in the activated sludge of WWTPs.

\section{Objective}

The aim of the present investigation was to develop a bacterial consortium isolated from different origins, to evaluate the ability of such consortium to remove a mixture of pharmaceuticals in batch system at lab scale, as well as assessment of its resistance to the other micropollutants present in the environment.

\section{Material and Methods}

\subsection{Chemicals and Reagents}

DCF, IBU, and SMX ( $\geq 99 \%$ purity) were purchased from Sigma-Aldrich. All organic solvents used for HPLC were Chromasol LC grade or equivalent. Ultra-pure water and HPLC grade formic acid were purchased from Sigma-Aldrich (Munich, Germany). HPLC grade acetonitrile was provided from Riedel de Häen (Steinheim, Germany). Isotopically labeled compounds used as internal standard were Diclofenac$d 4$ and Ibuprofen- $d 3$ purchased from Toronto Research Chemicals (Toronto, Canada). All chemicals used for the culture media preparation and other reagent used were purchased from Sigma-Aldrich or Fluka.

\subsection{Pure Cultures and Growth Conditions}

The pure bacterial cultures (D15, D16, S2, and S4) identified by their $16 \mathrm{~S}$ rRNA sequence as Enterobacter hormaechei, Citrobacter youngae, Arthrobacter nicotianae, and Pseudomonas sp. were previously isolated from household compost and activated sludge of the wastewater treatment plant of the Rabta (JijelAlgeria). The identification was carried out after the amplification of the 16S rRNA gene by PCR. The PCR product was purified and sequenced then compared using blast program with the nucleotide sequence database. Sequences were then deposited in the GenBank database, the given accession numbers are 
Aissaoui S et al.

Table 1. Bacterial strains used in the present study.

\begin{tabular}{|c|c|c|c|}
\hline Strains & Origin & Molecular identification & Accession number \\
\hline S2 & Household compost & $\begin{array}{c}\text { Arthrobacter nicotianae } \\
(99 \%)\end{array}$ & KJ740438 \\
\hline S4 & Activated sludge & $\begin{array}{l}\text { Pseudomonas sp. } \\
\qquad(97 \%)\end{array}$ & KJ740439 \\
\hline D15 & Activated sludge & $\begin{array}{c}\text { Enterobacter hormaechei } \\
(99 \%)\end{array}$ & KJ 863539 \\
\hline D16 & Household compost & $\begin{array}{c}\text { Citrobacter youngae } \\
(82.50 \%)\end{array}$ & - \\
\hline
\end{tabular}

listed in Table 1.

Each strain was grown individually in the nutrient broth for $24 \mathrm{~h}$ at $37^{\circ} \mathrm{C}$ and then plated on nutrient agar. After incubation, the agar plates were stored at $4^{\circ} \mathrm{C}$. These four bacterial strains were chosen due to their demonstrated ability to resist and degrade pharmaceuticals. Biodegradation experiment was conducted in the minimal mineral salt medium (MMSM) containing the following ingredients: $\mathrm{FeSO}_{4} \cdot 7 \mathrm{H}_{2} \mathrm{O}$ (0.013 g.L $\left.\mathrm{L}^{-1}\right), \mathrm{CaCl}_{2} \cdot 2 \mathrm{H}_{2} \mathrm{O}\left(0.013\right.$ g.L $\left.\mathrm{L}^{-1}\right), \mathrm{MgSO}_{4} \cdot 7 \mathrm{H}_{2} \mathrm{O}$ $\left(0.25\right.$ g. $\left.\mathrm{L}^{-1}\right), \mathrm{Na}_{2} \mathrm{HPO}_{4}\left(7.5\right.$ g.L $\left.\mathrm{L}^{-1}\right), \mathrm{KH}_{2} \mathrm{PO}_{4}\left(5\right.$ g.L $\left.\mathrm{L}^{-1}\right)$, $\mathrm{NH}_{4} \mathrm{NO}_{3}\left(5\right.$ g.L.- $\left.{ }^{-1}\right), \mathrm{pH} 7$ (19).

\subsection{Resistance of the Pure Bacterial Strains to Pharmaceutical Mixture}

Each bacterial strain (D15, D16, S2, and S4) was grown in the nutrient broth up to mid-logarithmic growth phase, after which cells were harvested by centrifugation at $4300 \times g$ for $5 \mathrm{~min}$, washed twice with saline solution and resuspended in distilled water (OD at $600_{\mathrm{nm}} 0.9$ ). The obtained suspensions were mixed (with equal volumes) and used to inoculate $100 \mathrm{~mL}$ Erlenmeyer containing $50 \mathrm{~mL}$ of MMSM and the drug mixture (DCF, IBU, and SMX) at the final concentration of $3 \mathrm{mg} \cdot \mathrm{L}^{-1}$ for each pharmaceutical. Media were incubated at $37^{\circ} \mathrm{C}$ under shaking condition (150 rpm) for $48 \mathrm{~h}$. Bacterial growth was monitored by measuring bacterial optical density OD at $600 \mathrm{~nm}$ every $2 \mathrm{~h}$ using a spectrophotometer. This test was conducted in duplicates (20).

\subsection{Antagonism Test}

Prior to the testing the ability of the mixed bacteria to degrade the drug mixture (DCF, IBU, and SMX), inhibition test was conducted to determine if the four bacterial strains (D15, D16, S2, and S4) could grow together successfully. For achieving this objective, $0.1 \mathrm{~mL}$ of the test bacterial suspension $\left(\approx 10^{8} \mathrm{CFU}\right.$. $\left.\mathrm{mL}^{-1}\right)$ was spread on the top of nutrient agar plates. Filter paper discs containing $20 \mu \mathrm{L}$ of the second bacterial suspension $\left(\approx 10^{8} \mathrm{CFU} \cdot \mathrm{mL}^{-1}\right)$ was deposited on the inoculated agar plates. Discs without bacterial suspension were used as the control. The plates were incubated for 24- $48 \mathrm{~h}$ at $37^{\circ} \mathrm{C}$ and visually monitored to check for any bacterial inhibition. The experiment was carried out in triplicates (21), as well.

\subsection{Biodegradation Tests}

Biodegradation experiments of the drug mixture by the mixed bacteria (D15, D16, S2, and S4) were carried out using a closed bottle test for the assessment of ready biodegradability of chemicals with slight modifications (22). A total volume of $100 \mathrm{~mL}$ of MMSM was inoculated with $5 \%$ of an overnight culture of the mixed bacteria which was previously washed with sterile normal saline. The inoculum was set to obtain a similar initial biomass density for each flask. Pharmaceuticals were spiked into the culture medium to a concentration of approximately $3 \mathrm{mg} . \mathrm{L}^{-1}$ for each drug from a stock solution prepared in the methanol and water (10:90 $\mathrm{V} / \mathrm{V})$.

The capacity of the enriched mixed bacteria to degrade drug mixture in the presence of additional carbon source was also tested. In this case, $50 \mathrm{mg} . \mathrm{L}^{-1}$ of glucose was added to the culture medium. To assess abiotic losses and/or adsorption of DCF, IBU, and SMX onto cells, controls were included in all assays; without inoculum and with autoclaved biomass (5\%), respectively. Samples were then incubated for $48 \mathrm{~h}$ at $37^{\circ} \mathrm{C}$ with shaking at $150 \mathrm{rpm}$. Bacterial growth was measured via optical density at $600 \mathrm{~nm}$ using Amersham UV-Visible spectrophotometer. To monitor the concentration of DCF, IBU, and SMX, samples of $2 \mathrm{~mL}$ were taken at the regular time (every $24 \mathrm{~h}$ ), centrifuged at $4300 \times g$ for $20 \mathrm{~min}$, and filtered through a Millipore filter $(0.22 \mu \mathrm{m})$ directly in amber vials for HPLC analysis.

\subsection{HPLC Analysis}

Time evolution of DCF, IBU, and SMX concentration during the experiments was followed using an HPLC- 
UV (Agilent Technologies, series 1100) provided with a C-18 column (Luna $5 \mu, 3 \times 150 \mathrm{~mm}$ from Phenomenex). A mixture of acetonitrile (25\%), ultra-pure water $(65 \%)$ and $25 \mathrm{mM}$ of formic acid (10\%) at a flow rate of 0.5 Ml. $\mathrm{min}^{-1}$ was used as mobile phase. Pharmaceutical concentrations were determined at a wavelength of $270 \mathrm{~nm}$. The injection volume was $20 \mu \mathrm{L}$. The peak area of DCF, SMX, and IBU was used to estimate the percentage of degradation using the following equation (1) (23).

$$
E I(\%)=\frac{C i-C 0}{C 0}(100)
$$

Where EI (\%) represents the pharmaceutical removal rate (\%), $C_{0}$ is the peak area of the selected drug in the beginning of the experiment and $C_{i}$ in the end.

\subsection{Susceptibility of the Bacteria Strains to Antibiotics and Heavy Metals}

In this test, the resistance of the selected bacteria able to degrade pharmaceuticals to another pollutant was tested. To evaluate the resistance/sensitivity to antibiotics, disc diffusion test was performed using commercial antibiotic discs (Colistin sulfate $\mathrm{CT}_{50}$, Sulphonamide compound $\mathrm{S}_{300}$, Amoxycillin $\mathrm{AML}_{25}$, Penicillin $\mathrm{G} \mathrm{P}_{10}$, Ampicillin $\mathrm{AM}_{10}$ Tetracycline $\mathrm{TET}_{30}$, Trimethoprim sulfamethoxazole $\mathrm{SXT}_{25}$, Erythromycin ERY15, Gentamicin GEN 10) on Muller-Hinton agar, and an overnight culture of the selected bacteria (OD 0.08 at $600 \mathrm{~nm}$ ). The samples were incubated at $37^{\circ} \mathrm{C}$ for $24 \mathrm{~h}$. Zones of inhibition were determined by measuring the diameter of the clear zone around the disc. In order to evaluate the resistance of these bacteria to some heavy metals [lead $(\mathrm{Pb})$ and Mercury $(\mathrm{Hg})]$, the growth of the strains in the nutrient broth containing $25 \mathrm{mg} . \mathrm{L}^{-1}$ of the selected heavy metal at $37^{\circ} \mathrm{C}$ under shaking $(150 \mathrm{rpm})$ during $24 \mathrm{~h}$ was examined by measuring absorbance at $600 \mathrm{~nm}$.

\section{Results}

\subsection{Pure Bacterial Strains Tolerance to Pharmaceutical Mixture and Antagonism Test}

The growth of the selected pure bacteria (D15, D16, S2, and S4) in MMSM containing pharmaceutical mixture (DCF, IBU, and SMX) is presented in Figure 1. As shown in this figure, the four isolates are able to grow in the presence of the drug mixture with different growth rates. The strain $\mathrm{S} 4$ showed a fast and maximal growth after $24 \mathrm{~h}$ of incubation (OD 1.151) with a growth rate of $1.5 \mathrm{~h}^{-1}$, after that, a decrease in the cell growth was observed. While the growth of the other strains (D15,

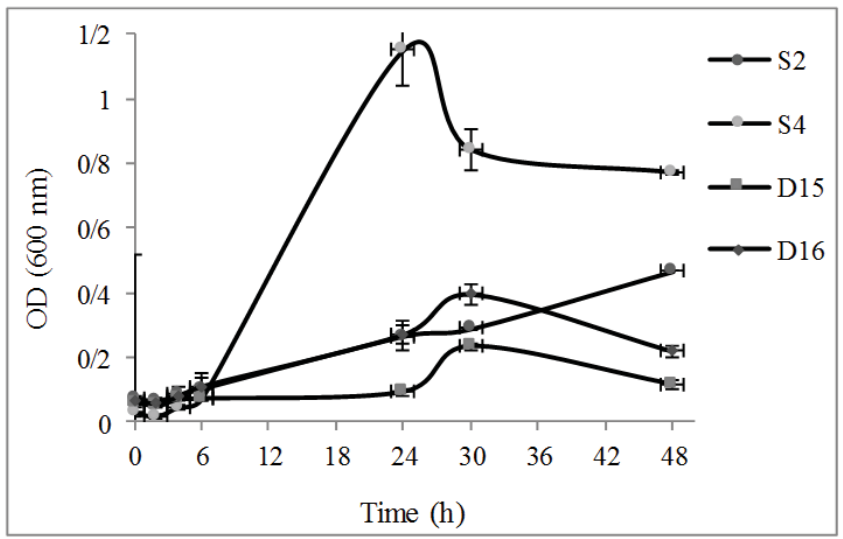

Figure 1. Growth pattern of the pure bacterial strains (S2, S4, $\mathrm{D} 15$, and D16) in MMSM in the presence of pharmaceutical mixture (SMX, DCF, and IBU at $3 \mathrm{mg} \cdot \mathrm{L}^{-1}$ ) at $37^{\circ} \mathrm{C}$ for $48 \mathrm{~h}$.

D16, and S2) remains in a slower exponential phase until $28 \mathrm{~h}$ of incubation, after that, a decrease of the cell growth was recorded except for the strain S2 where the cell growth continue to increase until $48 \mathrm{~h}$.

It is important to mention that the antagonistic test, as carried out in co-culture plates did not reveal any inhibition zones around the bacterial cultures which indicated that the isolates D15, D16, S2, and S4 are able to grow simultaneously within a complementary association, probably by developing a metabolic cooperation. This will allow a better optimization of the pharmaceuticals biodegradation by the mixed cultures.

\subsection{Biodegradation of the Drug Mixture}

Results of the inhibition test indicated that the four bacterial strains were able to survive in the association since no inhibition zone was seen. Figure 2 shows the biodegradation of the pharmaceutical mixture (DCF, IBU, and SMX) by the bacterial consortium (Enterobacter hormaechei, Citrobacter youngae, Arthrobacter nicotianae, and Pseudomonas sp.) without (Fig. 2A) and with the addition of glucose (Fig. 2B). The obtained results revealed that the concentration of the three drugs remained unchanged in the adsorption and abiotic samples (data not shown), indicating that abiotic and adsorption losses of DCF, IBU, and SMX in this study might be ignored. Bacterial consortia were able to grow in the presence of drug mixture, as shown in Figure 2. Figure 3 shows the typical HPLC chromatograms obtained at the beginning and at the end of the degradation experiment in co-metabolic conditions. In biotic samples, applying HPLC for monitoring drug concentration revealed that in metabolic conditions (i.e., the absence of glucose) the mixed bacteria were capable of eliminating $13.4 \%$ and $23.08 \%$ of IBU after 
Aissaoui S et al.
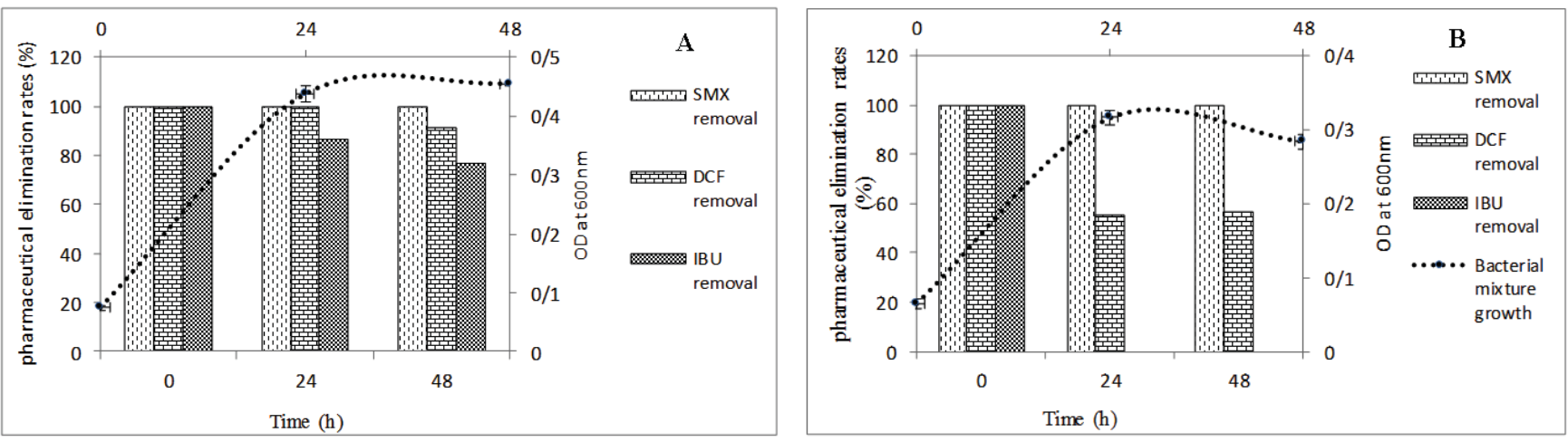

Figure 2. Biodegradation of the drug mixture (SMX, DCF, and IBU) by the mixed bacteria (S2, S4, D15, and D16). A: drug as the sole source of carbon and energy ( $<<0.05$ after $24 \mathrm{~h} ; \mathrm{p}<0.001$ after $48 \mathrm{~h}$ ), B: in the presence of glucose as the external carbon source ( $<0.001$ after $24 \mathrm{~h}$ and $48 \mathrm{~h})$.

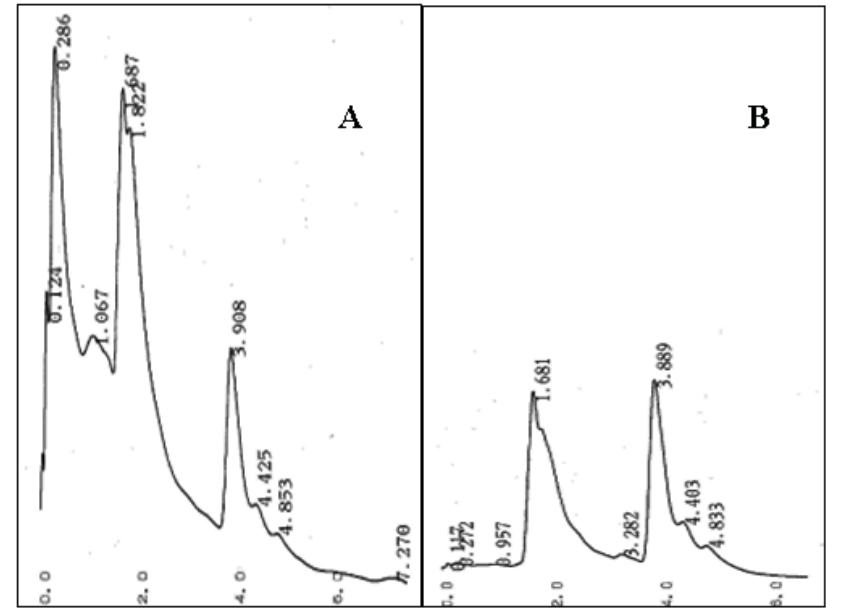

Figure 3. HPLC chromatograms of the biological removal assay of the drugs' mixture by the bacterial consortium in cometabolic conditions, at $\mathrm{t}_{0}(\mathrm{~A})$ and after $24 \mathrm{~h}(\mathrm{~B})$. Rt of SMX (4.853 $\mathrm{min})$, DCF (4.425 $\mathrm{min})$ and IBU (1.822 $\mathrm{min})$.
24 and 48 h of incubation, respectively. For DCF only $9.12 \%$ of the total concentration was removed after 48 $\mathrm{h}$ of incubation. Whereas in co-metabolic conditions (in the presence of glucose), a total elimination of IBU was recorded and for DCF $56 \%$ of the total concentration was eliminated after $48 \mathrm{~h}$ of incubation. In both metabolic and co-metabolic conditions, removal of SMX was not observed.

\subsection{Susceptibility of Bacterial Isolates to Antibiotics and Heavy Metals}

In this experiment the tolerance of the selected bacteria (S2, S4, D15, and D16) to different antibiotics and heavy metals was checked. The results showed that all bacterial strains were resistant to penicillin $G$, ampicillin, trimethoprim SMX, and erythromycin, and were sensitive to colistin sulfate, tetracycline, and gentamicin. Regarding sulfonamide compounds, all the

Table 2. Multidrug resistance of the bacterial strains able to eliminate pharmaceuticals.

\begin{tabular}{|c|c|c|c|c|c|}
\hline \multicolumn{2}{|c|}{ Strains } & \multirow[t]{2}{*}{ S2 } & \multirow[t]{2}{*}{ S4 } & \multirow[t]{2}{*}{ D15 } & \multirow[t]{2}{*}{ D16 } \\
\hline Antibiotic & $\begin{array}{c}\text { Antibiotic concentration } \\
(\mu \mathrm{g})\end{array}$ & & & & \\
\hline Colistin sulfate $\left(\mathrm{CT}_{50}\right)$ & 50 & $\mathrm{~S}$ & $\mathrm{~S}$ & $\mathrm{~S}$ & $\mathrm{~S}$ \\
\hline Sulfonamide Compound $\left(\mathrm{S}_{300}\right)$ & 300 & $\mathrm{R}$ & $\mathrm{S}$ & $\mathrm{R}$ & $\mathrm{R}$ \\
\hline Amoxycillin $\left(\mathrm{AML}_{25}\right)$ & 25 & $\mathrm{R}$ & $\mathrm{R}$ & $\mathrm{S}$ & $\mathrm{S}$ \\
\hline Penicillin $\mathrm{G}\left(\mathrm{P}_{10}\right)$ & 10 & $\mathrm{R}$ & $\mathrm{R}$ & $\mathrm{R}$ & $\mathrm{R}$ \\
\hline Ampicillin $\left(\mathrm{AM}_{10}\right)$ & 10 & $\mathrm{R}$ & $\mathrm{R}$ & $\mathrm{R}$ & $\mathrm{R}$ \\
\hline Tetracycline $\left(\mathrm{TET}_{30}\right)$ & 30 & $\mathrm{~S}$ & $\mathrm{~S}$ & $\mathrm{~S}$ & $\mathrm{~S}$ \\
\hline $\begin{array}{l}\text { Trimethoprime } \\
\text { Sulfamethoxazole }\left(\mathrm{SXT}_{25}\right)\end{array}$ & 25 & $\mathrm{R}$ & $\mathrm{R}$ & $\mathrm{R}$ & $\mathrm{R}$ \\
\hline Erythromycin $\left(\mathrm{ERY}_{15}\right)$ & 15 & $\mathrm{R}$ & $\mathrm{R}$ & $\mathrm{R}$ & $\mathrm{R}$ \\
\hline Gentamicin $\left(\mathrm{GEN}_{10}\right)$ & 10 & $\mathrm{~S}$ & $\mathrm{~S}$ & $\mathrm{~S}$ & S \\
\hline
\end{tabular}

R: Resistant, S: Sensitive 


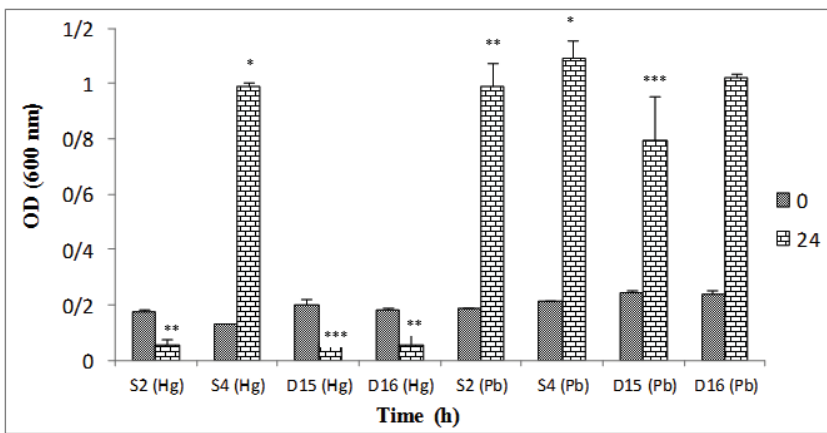

Figure 4. Cell growth of the strains (S2, S4, D15, and D16) in MMSM in presence of $25 \mathrm{mg} . \mathrm{L}^{-1}$ of mercury $(\mathrm{Hg})$ and 25 mg. $\mathrm{L}^{-1}$ of lead $(* \mathrm{p}<0.05 ; * * \mathrm{p}<0.01 ; * * * \mathrm{p}<0.001)$.

isolates were resistant, except the strain S4. In the case of amoxicillin, strains S2, and S4 were resistant while the two other strains (S15 and D16) were found to be sensitive (Table 2).

The results obtained for bacterial strains tolerance toward heavy metals revealed that, in the presence of mercury, a decrease in the cell growth for most bacterial strains was observed except for the strain S4 for which the cell growth was highly increased $(\mathrm{OD}=0.99)$. In the case of lead, all bacterial strains (S2, S4, D15, and D16) were able to grow in the presence of this heavy metal with a highly increased rate of cell growth $(\mathrm{OD}=0.991$, 1.093, 0.795, and 0.888) (Fig. 4).

\section{Discussion}

It is obvious that bacterial growth is directly correlated with the use of carbon source, which is one of the important factors studied in biodegradation experiments (24). In this work, the fact that the selected bacteria (D15, D16, S2, and S4) were able to grow in the presence of a pharmaceutical mixture as a sole source of carbon and energy, has provided evidence that these strains have the ability to use at least one of these micropollutants as substrate, resulting in their degradation. It should be notified that the bacterial strains used in this study were previously acclimated to the studied pharmaceuticals which facilitated their adaptation. It was reported that the adaptation of microorganisms to xenobiotic substrates requires time and the affinity of the bacterial enzymes for the substrates which influences their transformation rate (20). Because of their complexity, the metabolic pathways involved in the utilization of pharmaceutical mixtures by microorganisms are not easy to understand.

In this study, the absence of adsorption and abiotic elimination of the three pharmaceuticals used in this study gives evidence that any decrease in drugs' concentration can be attributed exclusively to the microbial activity. Consequently, the ability of the studied bacteria to resist and remove a mixture of drugs to the different rates presents a significant advantage for bioremediation of the pharmaceutical wastes.

The use of a drugs mixture in the presence of a consortium of bacterial strains may reflect the real situation in the environment and WWTP where pharmaceuticals and other pollutants are present as mixtures (6). The harmful effect of such mixtures on the microbial growth is higher than that of a single drug, this was reported by Kraigher et al. (25) where a mixture of five acidic pharmaceuticals ibuprofen, naproxen, ketoprofen, diclofenac, and clofibric acid at the final concentration of $50 \mu \mathrm{g} . \mathrm{L}^{-1}$ caused shifts in the bacterial community composition and reduced bacterial diversity, as well. In addition, the elimination of micropollutants by the mixed cultures of bacteria and fungi is better than by using pure strains (26). Because in the environment, bioremediation process naturally depends on the cooperation of metabolic activities of the mixed microbes; the benefice of this population can be attributed to the important metabolic capacities and the synergistic effect between associated members. For example, some species can remove the toxic metabolites of the preceding species and others can degrade compounds which the first species are able to partially degrade, promoting co-metabolic processes (27). Several studies reported that the use of microbial consortia increased the biodegradation rate of xenobiotics $(6,28)$. In this context, Reis et al. (17) have studied biodegradation of SMX by pure (Achromobacter) and the mixed bacterial cultures. They revealed that mixed bacteria exhibited a higher biodegradation performance when compared to a single microbial strain. In contrast, the elimination rate of SMX using pure Rhodococcus equi is more important than in the presence of mixed bacteria (19).

Furthermore, our results are in agreement with those obtained by Rodarte Morales et al. (18), which reported that the three ligninolytic fungi were able to remove a mixture of drugs with different elimination rates. A total degradation of SMX, citalopram, DCF, IBU, naproxen, and carbamazepine was achieved after 14 days, while for fluoxetine and diazepam lower removal percentages were obtained (i.e., 23 to $57 \%$ ). In another study conducted by the same authors, biotransformation of a mixture of three anti-inflammatories (DCF, IBU, and naproxen) by pellets of Phaerochaete chrysosporium in fed-batch bioreactors operating under continuous air supply or periodic pulsation of oxygen was investigated. They observed a total elimination of DCF and IBU in both aerated and oxygenated reactors with a 
fast oxidation of DCF in the presence of oxygen $(77 \%$ after $2 \mathrm{~h}$ ). In the case of naproxen, it was oxidized in the range of 77 up to $99 \%$ under both air and oxygen supply (29).

According to the obtained results, the elimination rate of the target pharmaceuticals in the presence of glucose was higher than that shown in its absence where IBU was totally removed. The simultaneous utilization of supplement carbon source with a compound that is less energetic may sustain cell growth and act as an electron donor, facilitating biodegradation of that compound. This may explain the high removal rate of IBU and DCF in the presence of glucose. The use of co-metabolism is to initiate a conversion reaction of the persistent compounds to their intermediates that are probably more biodegradable and therefore would join the central metabolic pathway for further biotransformation (30). Quintana et al. (1) have studied biodegradation of five acidic pharmaceuticals in the presence and absence of an external carbon source (powder milk). They observed a co-metabolic degradation of naproxen, IBU, and bezafibrate. In contrast, ketoprofen was found to be degraded in the absence of additional carbon source after a lag phase of 10 days. In another study, the strain Planococcus sp. S5 was able to eliminate $30 \%$ of naproxen after 35 days as the sole source of carbon, while under co-metabolic conditions $75.14 \%$ and $86.27 \%$ of naproxen was removed in the presence of glucose and phenol, respectively (31).

Concerning SMX which was not eliminated in both metabolic and co-metabolic conditions, the bacterial populations used in the biodegradation tests might have developed resistance to it; the mechanism of which is not necessarily involving the antibiotic utilization. Albuquerque et al. (32) reported that in the presence of the multi-substrate, each population uses its preferred substrate, while the other carbon sources are left available for other microbial groups (32). This could explain the non-biodegradability of SMX in our experiment.

To test the capacity of the used isolates to survive the conditions of the WWTP, the ability of the strains to resist to some antibiotics and heavy metals was tested. These two pollutants can reach the environment through discharge of industrial and WWTP effluent containing heavy metals and antibiotics. It is known that antibiotics and heavy metals can inhibit or kill bacteria, but in some cases these microorganisms can resist and survive due to their ability to neutralize and escape the effect of these compounds (33). The multi-resistance of heavy metals and antibiotics by bacteria from the environment was reported by several researchers (34-
36). The increase of antibiotic and heavy metal resistant bacteria is due to the genetic flexibility of the bacteria and their capacity to attain and transfer resistance genes (33).

In addition to its capacity to degrade drugs such as DCF and IBU, our bacterial consortium is resistant to the antibiotics and some heavy metals (i.e., lead and mercury), which allowed it to survive in the highly contaminated ecosystems or WWTPs. However, the antibiotic resistance should raise our concern regarding the uncontrolled release of antibiotics in the environment. The inappropriate disposal of drugs in the environment, namely antibiotics should be controlled by authorities through rigorous regulations; at a long term, this will significantly contribute to the reduction of their impact on the environment and health. The results suggest that Enterobacter hormaechei, Arthrobacter nicotianae, Pseudomonas sp., and Citrobacter youngae have a great potential for bioremediation of some pharmaceutical-contaminated ecosystems namely with ibuprofen and diclofenac.

\section{References}

1. Quintana JB, Weiss S, Reemtsma T. Pathways and metabolites of microbial degradation of selected acidic pharmaceutical and their occurrence in municipal wastewater treated by a membrane bioreactor. Water Res. 2005;39:2654-2664. DOI: 10.1016/j. watres.2005.04.068

2. Huerta B, Rodríguez-Mozaz S, Barceló D. Pharmaceuticals in biota in the aquatic environment: analytical methods and environmental implications. Anal Bioanal Chem. 2012;404(9): 2611-2624. DOI: 10.1007/s00216-012-6144-y

3. Pomati F, Orlandi C, Clerici M, Luciani F, Zuccato E. Effects and interactions in an environmentally relevant mixture of pharmaceuticals. Toxicol Sci. 2008;102(1):129-137. DOI:10.1093/toxsci/kfm291

4. Hester RE, Harrison RM. 2015. Pharmaceuticals in the Environment: Vol 41. Royal Society of Chemistry 41:92-119. DOI:10.1039/9781782622345

5. Silva BF, Jelic A, Lopez-Serna R, Mozeto AA, Petrovic M, Barcelo D. Occurrence and distribution of pharmaceuticals in surface water, suspended solids and sediments of the Ebro river basin, Spain. Chemosphere. 2011;85:1331-1339. DOI: 10.1016/j.chemosphere.2011.07.051

6. Mishra A, Anushree M. Novel fungal consortium for bioremediation of metals and dyes from mixed waste stream. Bioresour Technol. 2014;171:217-226. DOI: http://dx.doi. org/10.1016/j.biortech.2014.08.04

7. Cirja M, Ivashechkin P, Schaffer A, Corvini PFX. Factors affecting the removal of organic micropollutants from wastewater in conventional treatment plants (CTP) and membrane bioreactors (MBR). Rev Environ Sci Biotechnol. 2008,7:61-78. DOI: 10.1007/s11157-007-9121-8

8. Omil F, Suárez S, Carballa M, Reif R, Lema JM. Criteria for designing sewage treatment plants for enhanced removal of organic micropollutants. Environ Pollution. 2010,16:283-306. 
DOI: $10.1007 / 978-90-481-3509-7 \_16$

9. Fent K, Weston A, Caminada D. Ecotoxicology of human pharmaceuticals. Aqua Toxicol. 2006;76:122-159 DOI:10.1016/j.aquatox.2005.09.009

10. Velagaleti R. Behavior of pharmaceutical drugs (human and animal health) in the environment. Drug Information J.1997;31:715-722. DOI:10.1177/009286159703100311

11. Hata T, Kawai S, Okamura H, Nishida T. Removal of diclofenac and mefenamic acid by the white rot fungus Phanerochaete sordida YK-624 and identification of their metabolites after fungal transformation. Biodegradation. 2010; 21:681-689. DOI: 10.1007/s10532-010-9334-3

12. Nilambari D, Dhanashree T. Isolation and 16s rRNA sequence analysis of beneficial microbes isolated from pharmaceutical effluent. Bionano Frontier. 2014; 7(2):243-248.

13. Jiang B, Li A, Cui D, Cai R, Ma F, Wang Y. Biodegradation and metabolic pathway of sulfamethoxazole by Pseudomonas psychrophila HA-4, a newly isolated cold-adapted sulfamethoxazole-degrading bacterium. Appl Microbiol Biotechnol. 2013;98(10):4671-4681. DOI 10.1007/s00253-0135488-3.

14. Evangelista S, Cooper D, Yargeau V. The effect of structure and a secondary carbon source on the microbial degradation of chlorophenoxy acids. Chemosphere. 2010;79:1084-1088. DOI: 10.1016/j.chemosphere.2010.03.018

15. Wang Y, Wang C, Li A, Gao J. Biodegradation of pentachloronitrobenzene by Arthrobacter nicotianae DH19. Lett Appl Microbiol.2015;61(4):403-10. DOI: 10.1111/lam.12476.

16. Backhaus T. Medicines, shaken and stirred: a critical review on the ecotoxicology of pharmaceutical mixtures. Phil Trans $R$ Soc B. 2014;369:20130585. DOI: 10.1098/rstb.2013.0585

17. Reis PJM, Reis AC, Ricken B, Boris A, Kolvenbach, Manaia CM, Corvini P FX, Nunes O C. Biodegradation of sulfamethoxazole and other sulfonamides by Achromobacter denitrificans PR1. J Hazard Mater. 2014;280:741-749. DOI: 10.1016/j.jhazmat.2014.08.039

18. Rodarte-Morales I, Feijoo G, Moreira MT, Lema J. Degradation of selected pharmaceutical and personal care products (PPCPs) by white-rot fungi. World J Microbiol Biotechnol. 2011; 27:1839-1846. DOI : 10.1007/s11274-010-0642-x

19. Larcher S, Yargeau V. Biodegradation of sulfamethoxazole by individual and mixed bacteria. Appl Microbiol Biotechnol. 2011;91:211-218. DOI: 10.1007/s00253-011-3257-8

20. Almeida B, Oehmen A, Marques R, Brito D, Carvalho G, Barreto Crespo MT. Modelling the biodegradation of nonsteroidal antiinflammatory drugs (NSAIDs) by activated sludge and a pure culture. Bioresour Technol. 2013;133:31-37. DOI: 10.1016/j. biortech.2013.01.035

21. Marin-Cevada V, Munoz-Rojas J, Caballero-Mellado J, Mascarua-Esparza M, Castaneda-Lucio M, Carreno-Lopez $\mathrm{R}$, et al. Antagonistic interactions among bacteria inhabiting pineapple. Appl Soil Ecol.2012; 61:230-235. DOI:10.1016/j. apsoil.2011.11.014

22. Organization of Economic Cooperation and Development (OECD). (1992). OECD, Guideline for Testing Chemicals Ready Biodegradability.http://www.oecd.org/

23. Zwiener C, Frimmel FH. Short-term tests with a pilot sewage plant and biofilm reactors for the biological degradation of the pharmaceutical compounds clofibric acid, ibuprofen, and diclofenac. Sci Total Environ. 2003;309:201-211. DOI:10.1016/ S0048-9697(03)00002-0
24. Singh P, Mishra L C, Pandey A, Iyengar L. Degradation of 4-aminobenzenesulfonate by alginate encapsulated cells of Agrobacterium sp. PNS-1. Bioresour Technol. 2006;97:16551659. DOI:10.1016/j.biortech.2005.08.002

25. Kraigher B, Kosjek T, Heath E, Kompare B, Mandic-Mulec I. Influence of pharmaceutical residues on the structure of activated sludge bacterial communities in wastewater treatment bioreactors. Water Res. 2008;42:4578-4588. DOI:10.1016/ j.watres. 2008.08.006

26. Nguyen LN, Hai FI, Yang S, Kang J, Leusch FDL, Roddick $\mathrm{F}$, et al. Removal of trace organic contaminants by an MBR comprising a mixed culture of bacteria and white-rot fungi. J Bioresour Technol. 2013;148:234-241. DOI: 10.1016/j. biortech.2013.08.142

27. Cerqueira VS, Hollenbach EB, Maboni F, Vainstein MH, Camargo FA, do Carmo R Peralba M, Bento FM. Biodegradation potential of oily sludge by pure and mixed bacterial cultures. Bioresour Technol. 2011;102(23):11003-10. DOI: 10.1016/j.biortech. 2011. 09.074

28. Mikeskova H, Novotny C, Svobodova K. Interspecific interactions in mixed microbial cultures in a biodegradation perspective. Appl Microbiol Biotechnol. 2012;95:861-870. DOI : $10.1007 / \mathrm{s} 00253-012-4234-6$

29. Rodarte-Morales I, Feijoo G, Moreira MT, Lema J. Biotransformation of three pharmaceutical active compounds by the fungus Phanerochaete chrysosporium in a fed batch stirred reactor under air and oxygen supply. Biodegradation. 2012;23:145-156. DOI : 10.1007/s10532-011-9494-9

30. Groning J, Held C, Garten C, Claubnitzer U, Kaschabek SR. Schlomann M. Transformation of diclofenac by the indigenous microflora of river sediments and identification of a major intermediate. Chemosphere. 2007;69:509-516. DOI: 10.1016/j. chemosphere.2007.03.037

31. Domaradzka D, Guzik U, Hupert-Kocurek K, Wojcieszyńska D. Co-metabolic degradation of naproxen by Planococcussp. strain S5. Water Air Soil Pollut; 2015,226:297. DOI:10.1007/ s11270-015-2564-6

32. Albuquerque M, Carvalho G, Kragelund C, Silva AF, Barreto Crespo MT, Reis MA M, Nielsen PH. Link between microbial composition and carbon substrate-uptake preferences in a PHAstoring community. ISME J. 2013;7(1):1-12.DOI: 10.1038/ ismej. 2012.74

33. Al-Gheethi A, Lalung J, Ali Noman E, Bala JD, Norli I. Removal of heavy metals and antibiotics from treated sewage effluent by bacteria. Clean Technol Environ. 2015;17(8):2101-2123. DOI: 10.1007/s10098-015-0968-z

34. Gulati D, Goyal P. Identification and multiple drug resistance of bacteria isolated from soil samples collected from pharmaceutical industrial Area. J Pharm Biomed Sci. 2014;04(11):984-994.

35. Beleneva IA, Kukhlevsky AD, Kharchenko UV, Yu LK. Resistance to copper ions and antibiotics in marine heterotrophic bacteria in the coastal waters of Vietnam. Russian J Marine Biol. 2011;37(4):284-290. DOI: 10.1134/S1063074011040043

36. Kimiran-Erdem A, OzlemArslan E, Ozlem SYN, Zeybek Z, Dogruoz N, Cotuk A. Isolation and identification of Enterococci from seawater samples: assessment of their resistance to antibiotics and heavy metals. Environ Monit Assess. 2007;125:219-228. DOI: 10.1007/s10661-006-9506-0. 